УДК $342.732: 321.7$

Czarnecki Pawel

Dr hab., profesor, $M B A$,

Rector of Warsaw Management University,

Warsaw, Poland,

rektor@wsm.warszawa.pl

\title{
FREEDOM OF THE MEDIA IN A DEMOCRATIC STATE
}

The aim of the article is to study what is media freedom; in particular, should the freedom of the media be undermined in the realities of independent states at all. In order to be able to take any consideration in the mentioned matter, we should first answer the question to what media freedom we refer to. We can understand it as the freedom of specific institutions or individuals involved in media activities. We can also understand it broadly as freedom to reject or accept any restrictions of a philosophical, ideological, moral or religious nature. The research methodology consists in using such methods as study, analysis and generalization with the purpose of discussion about media freedom should start with the realization that it is closely related to the general, philosophical discussion about the criteria of freedom and is exposed not only to limitations, but also to abuse. All mentioned areas are interrelated in a certain way the freedom of the individual involved in the media depends on the principles of the freedom of the institution with which he is bound. Freedom of institutions leads to freedom of the media in general, freedom of artistic expression, and finally freedom of speech. It is impossible to talk about freedom, including freedom of the media, without considering the value systems adopted in a particular state, social environment or a specific structure. In many place sit differs significantly, what creates the need to formulate some general ethical principles that would allow to distinguish necessary from unauthorized interference in the independence of media.

Key words: media freedom, media, freedom of journalists, independence, ethical rules, social environment, ethical responsibility.

Чарнецький Павел, доктор габілітований, професор, МВА, Ректор Варшавської вищої школи менеджменту, Варшава, Польща

\section{Свобода 3МІ у демократичній державі}

Мета статті - дослідити в чому полягає свобода ЗМІ, зокрема як вона реалізує себе в незалежних держав взагалі. Для того, щоб мати можливість врахувати будь-які міркування у згаданому питанні, спочатку ми повинні відповісти на питання, що ми маємо на увазі під поняттям свобода засобів масової інформації. Ми можемо зрозуміти це як свободу окремих установ чи осіб, задіяних у діяльності ЗМІ. Ми також можемо зрозуміти це в широкому 
розумінні як свободу відхилення або прийняття будь-яких обмежень філософського, ідеологічного, морального або релігійного характеру. Методологія дослідження полягає у вивченні, аналізі та узагальнені з метою усвідомлення поняття свободи ЗМІ як такого, що тісно пов'язано із загальною, філософською дискусією про критерії свободи і викривається не лише обмеженням, а й зловживанням. Усі зазначені сфери взаємопов'язані певним чином - свобода особи, задіяної в ЗМІ, залежить від принципів свободи інституту, з яким він пов'язаний. Свобода інституцій призводить до свободи ЗМІ в цілому, свободи художнього вираження i, нарешті, свободи слова. Не можна говорити про свободу, включаючи свободу засобів масової інформації, не враховуючи ціннісні системи, прийняті в певній державі, соціальне середовище або певну структуру. У багатьох місцях сидіння суттєво відрізняються, що створює необхідність сформулювати деякі загальні етичні принципи, які б дозволили відрізнити необхідність від несанкціонованого втручання в незалежність засобів масової інформації.

Ключові слова: свобода ЗМІ, ЗМІ, свобода журналістів, незалежність, етичні правила, соціальне середовище, етична відповідальність.

Pawet Czarnecki, Dr hab., profesor, MBA, Pektor Wyższej Szkoły Menedżerskiej $w$ Warszawie, Warszawa, Polska

\section{Wolność mediów w demokratycznym państwie}

Celem artykułu jest zbadanie, czym jest wolność mediów; w szczególności, gdyby wolność mediów była w ogóle podważana w rzeczywistości niepodległych państw. Żeby móc w ogóle podjąć rozważania w powyższym zakresie, należy przede wszystkim odpowiedzieć sobie na pytanie, do jakiej wolności mediów się odnosimy. Możemy ją rozumieć, jako wolność konkretnych instytucji, podmiotów lub pojedynczych osób zaangażowanych $\mathrm{w}$ działalność medialną. Możemy ją również pojmować, jako szeroko pojętą wolność środków przekazu, odrzucenie lub przyjęcie wszelkich ograniczeń o charakterze filozoficznym, ideologicznym, moralnym lub religijnym. Metodologia badawcza polega na wykorzystaniu takich metod, jak badanie, analiza i uogólnienie w celu dyskusji o wolności mediów należy zacząć od uświadomienia sobie, że jest ona ściśle związana z ogólną, filozoficzną dyskusją o kryteriach wolności i narażona nie tylko na ograniczenia, ale również nadużycia. Wszystkie wymienione obszary są ze sobą w pewien sposób powiązane - wolność jednostki zaangażowanej w media zależna jest od zasad działania wolności instytucji, z którą jest ona związana. Wolność tej natomiast sprowadza się do wolności środków przekazu, mediów w rozumieniu ogólnym, wyrazu artystycznego, w końcu również wolności słowa. Nie da się mówić o wolności, także wolności mediów, bez rozważania na temat przyjętych $\mathrm{w}$ danym państwie, środowisku czy konkretnej strukturze systemów wartości. W wielu miejscach znacznie się one od siebie różnią, co rodzi potrzebę sformułowania pewnych ogólnych zasad etycznych, które pozwoliłyby na 
rozróżnienie między potrzebną a nieupoważnioną ingerencją w niezależność środowisk medialnych.

Słowa kluczowe: wolność mediów, media, wolność redakcyjna, niezależność, normy etyczne, środowisko społeczne, odpowiedzialność etyczna.

Чарнецкий Павел, доктор габилитований, профессор, МВА, ректор Варшавской высшей школы менеджмента, Варшава, Польша

\section{Свобода СМИ в демократическом государстве}

Цель статьи - исследовать в чем заключается свобода СМИ, в частности как она реализует себя в независимых государств вообще. Для того, чтобы иметь возможность учесть любые рассуждения в упомянутом вопросе, сначала мы должны ответить на вопрос, что мы имеем в виду, говоря о свободе средств массовой информации. Мы можем понять это как свободу отдельных учреждений или лиц, задействованных в деятельности СМИ. Мы можем понять это в широком смысле как свободу отклонения или принятия каких-либо ограничений философского, идеологического, морального или религиозного характера. Методология исследования заключается в изучении, анализе и обобщений с целью осознания понятия свободы СМИ как такового, что тесно связано с общей, философской дискуссией о критериях свободы и разоблачается не только ограничением, но и злоупотреблением. Все указанные сферы взаимосвязаны определенным образом - свобода личности, задействованной в СМИ, зависит от принципов свободы института, с которым он связан. Свобода институтов приводит к свободе СМИ в целом, свободы художественного выражения и, наконец, свободы слова. Нельзя говорить о свободе, включая свободу средств массовой информации, не учитывая ценностные системы, принятые в определенном государстве, социальная среда или определенную структуру. Во многих местах сиденья существенно отличаются, что создает необходимость сформулировать некоторые общие этические принципы, которые позволили отличить необходимость от несанкционированного вмешательства в независимость средств массовой информации.

Ключевые слова: свобода СМИ, СМИ, свобода журналистов, независимость, этические правила, социальная среда, нравственная ответственность.

Introduction. The freedom of media can be understood in different ways. One can speak of the freedom of media as an institution, connoting that there is an absence of any dependence of media on the legal and economic pressures. Secondly, the freedom of media can be understood as belonging to individual entities participating in media as such, their relationships and dependencies, and above all, the scope of their respective independence. Thirdly, the freedom of media can be understood as a rejection of any restrictions of ideological, philosophical, religious or moral character. 
In the last case, the discussion about the freedom of media is closely associated with the general, philosophical discussion about the limits and criteria of freedoms. Fourthly and finally, the freedom of media can be discussed in the context of various risks that the abuse of this freedom might create not only for an individual, but also for the society. In this article, I am going to discuss the freedom of media as it is understood under the last three definitions given above.

The aim of the article is to study what is media freedom; in particular, should the freedom of the media be undermined in the realities of independent states at all. In order to be able to take any consideration in the mentioned matter, we should first answer the question to what media freedom we refer to. We can understand it as the freedom of specific institutions or individuals involved in media activities. We can also understand it broadly as freedom to reject or accept any restrictions of a philosophical, ideological, moral or religious nature.

First of all, it should be noted that these three areas where the freedom of media becomes problematic are partially related to one another. One kind of 'microideology' seems to be, for example, the so-called programme line adopted by individual editors, being a set of beliefs and preferences (often political) whose acceptance forms a precondition for the employment in a given media house. The dependence of individual media employees on the place that they occupy in the whole media structure as well as the existing system of values and beliefs in such an organisation tends to be much greater than, for example, in cases of scientists.

Interestingly, many threats to the freedom of journalists resulting from their dependence on the employer in question are not always related to the economic or political interests. Quite often the independence of journalists is suppressed by their superiors for some irrational reasons. For example, a journalist of one of the newspapers belonging to the Norwegian syndicate Orkla said in a survey investigating the independence of journalists that he is allowed to take on essentially all subjects with the exception of those involving criticising their publishers and capital ownership. $\mathrm{He}$ also added that a much greater threat to his independence is posed by the prevailing relations in the editorial office. In his views, media employees are exploited by their employers, whereas the general interference in the press material is very far-reaching, sometimes leading to a factual change of its meaning. The journalists are also forced to strictly execute their given commands, even if these are contrary to their sense of dignity and ethical principles ${ }^{1}$ [21]. In many cases, journalists can realistically experience their freedoms only where they have the support of the editor-in-chief in question (or the director of a given programme in electronic media). In practice, therefore, the work of journalists and other media employees often comes down to carrying out someone else's freedoms.

\footnotetext{
${ }^{1}$ Compare with L. Pokrzycka, Kapitat zagraniczny w regionalnej prasie - szanse i zagrożenia dla dziennikarzy (analiza na przykładzie Lubelszczyzny), in: Media i demokracja..., p. 250.
} 
Therefore, this raises the need to formulate certain ethical rules which would allow to distinguish between an authorised interference in the independence of journalists on one hand, and an unauthorised interference on the other. For this reason, many authors point out to a separate group of standards governing the relations between journalists, especially within the same editorial environment. These include, among others, the principle of companionship involving the acceptance of a particular type of formal and informal relationships prevailing in the editorial office, the principle of loyalty, according to which a journalist should accept the editorial line of a given programme, or the principle of respect for the authority, which plays a significant role especially in the editorial offices with well-established traditions. In practice, these principles often become a source of numerous conflicts arising from the simple fact that working in media is a creative undertaking, whereas any given system of values and beliefs can sometimes turn out to be contrary to the views of individual journalists when it comes to certain issues. The change of the political system in Poland after 1989 did not weaken this type of conflict, and so the conclusion formulated in the early sixties of the last century by Aleksander Matejko is still relevant today. It was stated that in order to work in media, one has to posses the ability to "plastically adapt to changing situations" ${ }^{\text {[15]. }}$.

It seems that this rule applies only to the world of media, because no other professional environment does actually require to show respect to a given standpoint on social or political issues that prevail in certain contexts. Other professional ethical norms allow for the possibility of withdrawing from any given activity because of one's beliefs (for example, medical ethics). For all occupations, however, the rule requiring to care for the prestige of one's own working environment applies. And this principle requires, among other things, to undertake efforts to improve one's skills and to create specialised associations upholding the legitimate interests of a given profession $^{3}$ [17].

Another group of ethical standards should include various rules governing the relations of media with their social environment. Such standards seem to be particularly important for local media, which are subject to ostracism from their local environment to a much greater degree than national media. In this case, it is not just about the freedom to inform, but also about the freedom to present one's views, including the freedom of artistic expression in media. In local communities, there are often strong social ties (which, to quote one survey participant, are of "a journalistic, business and even cultural character") and any collegial criticism is very unwelcome ${ }^{4}$

2 Compare with A. Matejko, Postawy zawodowe dziennikarzy na tle systemu społecznego redakcji, Kraków 1962 - 1963.

${ }^{3}$ The first such association in Poland was the Association of Polish Journalists, established in 1895 and belonging to the International Association of Press. Compare with D. Nałęcz, Zawód dziennikarza w Polsce 1918 - 1939, Łódź 1982, p. 49 et seq.

${ }^{4}$ Compare with L. Pokrzycka, Kapitat zagraniczny..., p. 246. 
[21]. Any clear formulation of standards relating to the relationship of media with their local communities is difficult due to the existence of clearly marked divisions on specific issues or even values that prevail in such societies. In these instances, ordering journalists to transfer information without paying any regard as to its consequences would not always be right. Such freedom, however, should prevail in relation to the expressed views and opinions. And also local communities should equally adhere to the principle obliging to show respect for the freedom of expression of such views and opinions, thus refraining from any form of pressure and ostracism.

Privacy. The ethical responsibility of media relates, among others, to situations where someone's assets have been infringed. Such an asset could be the honour (the good name) or the image, and the way in which it can be infringed - the publication of information relating to the private life or false information. It is, therefore, necessary to limit media freedoms in these areas.

The privacy, as noted by T. Kononiuk, "is a value which cannot be clearly defined, but also a value without which human life would be unbearable"5 [13]. Despite this, the violation of privacy of public figures is sometimes justified by the common good. This happens when the respect for privacy might pose a threat to the common good of all. As noted by Z. Sareło, the more endangered the common good, the more justified the degree of invasion of privacy ${ }^{6}$ [22]. More controversy, however, can be raised in situations when the invasion of privacy does not harm the common good, but the disclosure of certain facts can actually serve it. This happens, for example, if the disclosure sheds a new, unfavourable light on a politician seeking a high state office position. The disclosure of this sort of information can help to change the decision of voters, and it is therefore fully justified.

What turns out to be more difficult is the ethical evaluation of the act of publishing of information about the life of publicly known persons who are not performing any public functions, for example, show-business celebrities, actors, artists, TV presenters and even well-known journalists. According to Z. Sareło, publishing of the details about their private lives is a violation of the dignity of a person, and so it is morally wrong. What is more, the author puts the blame here also on the consumers, because whether media publish this type of information depends on their interests. "This behaviour, as Sareło notes, is a kind of voyeurism and eavesdropping. (...) What is more, the recipients are to a certain extent the cause inspiring journalists to steal information, which other people rightly do not want to disclose"7 [17]. However, if the recipient accidentally stumbles across the information about one's private or intimate life, they should then behave in accordance with a principle governing secretive information which has been discovered by chance. This principle prohibits the

\footnotetext{
${ }^{5}$ T. Kononiuk, Prywatność w mediach, „Studia Medioznawcze” 2005, No. 1 (20), p. 30.

${ }^{6}$ Compare with Z. Sareło, Etyka społecznego..., p. 70.

${ }^{7}$ Op cit. note 6, p. 123.
} 
disclosure of any such secret and it requires to behave as if one has forgotten about the uncovered facts ${ }^{8}$ [24].

Another form of violation of the dignity of an individual seems to be the publication of information on the public life of a person who has given their consent to that, or who has even initiated it. This applies above all to those people who start their careers in the music industry or aspiring actors and who occasionally reveal some details about their private lives to media, hoping to attract attention. The degree of violation of the dignity is in such situations generally smaller, because these people do not disclose any embarrassing, libellous and unfavourable information. In addition to violating one's own dignity, these cases are also about a form of manipulation, because the recipient usually does not realise that a specific information constitutes in fact a fugitive marketing tactic used to accelerate one's career. It seems that this last reason is sufficient for media to refuse to publish any information submitted this way.

In Polish jurisprudence, the prevailing concept is that the right to privacy can be restricted only when it comes to people engaged in public work, and only when their activity is linked to the sphere of privacy. In other words, it is acceptable to publish only such information concerning their private lives which in some way relates to their activities undertaken in the public ${ }^{9}$ [19]. Without the consent of those in question, however, it is not allowed to publish any information relating to people who derive certain profits on account of their media image. It is worth noting that the latter prohibition may be the subject of a discussion, because some codes of ethics (for example, the Estonian Code $^{10}$ [11]) do allow for the interference in the privacy of those who benefit from the publication of their image. It is also possible to extend the scope of meaning of the concept of public activity, so that it refers to all entities that have a definite impact on the public sphere, and thus also those in show-business.

An interesting ethical argumentation ${ }^{11}$ was presented by the Court of Appeal in Warsaw in its judgment of 2004, in a case brought by a TV presenter, Monika Luft, against one of the newspapers [31]. It was stated that: "no one has the right to a onesided, hagiographic presentation of oneself and allowing to share information about one's private life weakens this protection"12 [11]. On the surface this argument does not seem to be based on sufficient ethical grounds (nor legal, as the court did not

\footnotetext{
${ }^{8}$ Compare with T. Ślipko, Zarys etyki szczegółowej, Kraków 1982, V. I, p. 360 et seq.

${ }^{9}$ Compare with K. Pietrzykowski, Tzw. ,interpretacyjne wyroki Trybunału Konstytucyjnego, „Przegląd Sądowy” 2004, No. 3, p. 16 et seq.

${ }^{10}$ The provisions of the Code of Ethics of the Estonian Press are different, however, from the laws in Estonia, and their publication caused much controversy.Compare with K. Kamińska, Obiektywizm $i$ samokontrola $w$ wypowiedziach estońskiej prasy codziennej na początku XXI wieku, in: Media a demokracja..., p. 289.

${ }^{11}$ In assessing this merit, M. Zaremba writes that "despite the appearances of a legal style (...) these considerations do not meet the requirements of a legal argument". Compare with M. Zaremba, Granice prawa obywateli..., p. 55.

${ }^{12}$ Ibid.
} 
specify them), but it is worth noting that media act according to this line of thinking. Therefore, it should be possible to identify a principle on which media could rely when publishing data on people known to the public but without their consent, or even against their will, or else all publications to which those persons did not consent should be considered morally reprehensible.

It should be noted that in the latter case we would have to consider media as a tool for promoting a positive image of celebrities (with the exception, at most, of a group of people undertaking public activities, but which is not tantamount to a group of people known publicly), because it is hard to imagine that anyone would agree to publish negative information about themselves. This position, however, seems to be an excessive restriction on the freedom of media. One can thus assume that the right of media to report on the private lives of those publicly known stems from a kind of 'contract' that is concluded between these two entities. The implication is that media are allowed to publish information about these people and their activities free of charge, so that they can derive certain benefits from it, while at the same time agreeing to be less protective when it comes to their privacy, thus driving certain benefits towards media (in a form of increased customer attention).

The adoption of this assumption would require to provide some answers to the question about the duration of the above-mentioned 'contract'. Can any such benefit recipient be entitled to regain their rights to a complete privacy upon withdrawing from public activities, or is it that the right of media to inform about their private lives lasts longer (for example, as long as the general public interest in that person persists)? In other words, the question here is about the 'border line' separating the state of being publicly known from the state of being publicly unknown. It appears that any answers here are conceivable only with reference to specific people and circumstances.

In addition, there is also a form of conflict that exists between the rights of media to report on the private lives of some people and the public interest. This is related to the fact that the decision to engage in the public-life activities, in particular of a political character, means a de facto resignation from the protection of private life. In practice, it may turn out that some outstanding individuals will not be capable to undertake that resignation and therefore they will not decide to engage in any activities for the common good. This may further have the consequence that matters concerning the whole of the society will be decided upon by people to whom getting rid of their privacy protection does not constitute any problem due to certain psychological traits (for example, being prone to narcissism). The history does also show that some prominent politicians were not exemplary husbands and fathers, and if media had in advance made this information known, then perhaps they would have never been allowed to conduct any public activity.

Another commodity that may be affected by media publication is the image. The core problem with image rights is all the more complicated by the lack of a clear definition of the term 'image', what does not mean that it is a trivial issue. 
The formulation of clear ethical principles (and also possibly legal) to protect the right to media image is all the more important because the attitude of media to those people and institutions presented in their coverage is often biased, and what is worse, one can even have the impression that over time it becomes more and more cynical and contemptuous.

The attempt to formulate a correct definition of the media image goes beyond the scope of this work, yet it is worth noting that it is not identical with the real understanding of the person in question ${ }^{13}$ [18]. The image is a way of functioning in media in a particular role (as an actor, artist or a singer), and so it is comparable with advertising, or at least with the ordinary packaging of products or services. It therefore seems that the ethical evaluation of media images can be subject to similar rules which are applicable to advertising. These standards exclude lying to the recipient (the customer) in order to create a positive opinion about any given product, however certain conventionality is allowed and its intensity depends on the degree to which the recipient realises that he or she is involved in some kind of game which differs from reality and which should not be taken literally.

Another area where the freedom of media is restricted is the scope of the journalistic secrecy (i. e. the right of media employees ${ }^{14}$ to withhold the disclosure of their information sources before a court). Precise regulations in this context are of particular importance, because the arrangement of relations between media and the political power depends on them. "The journalistic secrecy may become a tool to manipulate the public opinion, as pointed out by J. Sobczak, especially when it is in the hands of unethical and dishonest journalists. It is also impossible not to notice that it can be used to achieve short-term political goals" ${ }^{\prime 15}$ [25]. The legal situation in Poland is all the more interesting because journalistic secrecy is in fact more a matter of ethical than legal issue. In Poland, a journalist does indeed hold the right to maintain the confidentiality of their information sources, but there is no such obligation, and so it is his or her free decision whether when testifying as a witness before a court the possibility of invoking the secrecy will be relied upon ${ }^{16}$ [25]. The court may compel a journalist to reveal their information sources only in cases of particularly serious offenses (as defined in separate regulations) and it is only when there is no possibility of collecting that information in any other way.

13 The field of pubic relations deals with shaping the media image of companies and institutions, and this field is guided by its own relevant ethical principles. One of them is the true information about the condition of the company in question. Compare with Media, reklama i public relations, as edited by J. Olędzki, Warszawa 2005, p. 18. The above comments concern typically the image of people.

${ }^{14}$ This right includes not only journalists, but all media employees, including the secretaries.

${ }^{15}$ J. Sobczak, Tajemnica dziennikarska, „Studia Medioznawcze” 2005, No. 1 (20), p. 28.

${ }^{16}$ Ibid. p. 21 
The solutions to be found in the Polish law are certainly there to guard media freedoms, however to leave the decision on journalistic confidentiality for reporters themselves may prove objectionable. What also seems relevant here is that this type of legal situation imposes on journalists an additional obligation to inform those people providing information that the principle of secrecy is the sole and discretionary responsibility of the journalists themselves. This obligation can be considered as related to another duty, namely to inform what purposes one's answers in a questioning will be used for ${ }^{17}[4]$.

Many authors note that the assumption according to which media are interested in the strengthening of democracy and the shaping of public opinion (or, in a broader sense, the good of humanity) turns out to be wrong. They believe that in practice media are interested primarily in the pursuit of their own economic and political interests (whereas the dependence on the politicians is treated as a way of securing economic interests), and any ethical demands are met only in so far as they contribute to the economic strengthening of media. The belief that tends to soar in various media and ethics literature is that the relationship of media with advertisers and politicians poses the greatest threat to their freedoms ${ }^{18}[2]$.

Although it is obviously difficult to estimate the degree of dependence of media on various factors, generally speaking it seems that at least in some areas a greater threat to their freedom is posed by the prevailing belief in a given society ${ }^{19}$. One can indeed indicate several areas where such common views as to the 'correct' functions of media in the society can in fact become a cause of limitations to (or attempts to reduce) their very freedoms.

First of all, the whole concept of 'media space' can be treated as a product of a prevailing worldview of any given society or country. In this case, the conviction might be said to consist of a set of beliefs as to what should be the subject of public debate (or even as to what should be subject to being made public) and what should appear in this discussion ${ }^{20}$ [27]. Having said that, it seems appropriate to formulate a standard requiring to maximise the sphere of public debate by presenting to customers the widest possible spectrum of views, assessments and arguments. An example of such an ideological marginalization of certain content is, for example, the exclusion

\footnotetext{
${ }^{17}$ Compare with J. C. Bertrand, Deontologia mediów.., p. 96. The author also believes that "we should not reveal the questions that we intend to pose". This principle seems questionable, since in many cases the public will be better informed if the journalist leaves the caller enough time to reflect on the answers. It seems that this principle should be limited only to investigative journalism, which is concerned with the knowledge of facts and not their interpretation.

${ }^{18}$ Compare with A. Balsey, R. Chadwick, Ethics as a Vehicle for Media Quality, in: The Media and Morality, as edited by R. M. Baird, W. E. Loges, New York 2002, p. 56 et seq.

${ }^{19}$ By the term "worldview" I understand the whole spectrum of views on the social and political life, including on the role of media.

${ }^{20}$ Compare with J. B. Thompson, Media i nowoczesność. Społeczne teorie mediów, Wrocław 1996, p. 135.
} 
from publication of any information concerning various minorities or providing information in a way that it augments prejudices against such groups ${ }^{21}$. Of a similar character is also the provision in the Act on the National Broadcasting Council ordering to respect Christian values in media. In practice, this provision prohibits media from broadcasting any content that is contrary to the principles of Christian ethics, so for example content appearing to shed positive light on abortion or euthanasia ${ }^{22}$ [26].

Another set of beliefs applies to the concept of truth in media. Assuming that the duty of media is to provide truth and nothing but the truth, some people or institutions, with regard to whom media have provided false information, happened to file lawsuits for damages. In accordance with the applicable regulations and the interpretation of the principle of media freedoms in Poland, the courts ruled, however, that it is on the whole the duty of media to observe the process of due diligence in the collection and processing of information as well as the observance of subjectivity as to the veracity of the so collected material ${ }^{23}$ [3]. Accordingly, the ethical principle binding upon media is the principle of truthfulness and not the principle of an absolute truth. In the event that such information proves to be false, the duty of media is to publish a corrigendum.

These types of judgments are the result of the need to reconcile two contradictory arguments: the right of media to provide information and the right to gather it, whereas the latter is incomparably more modest when compared with the rights of the law enforcement for instance. Such a compromise solution, however, does seem to pose a threat to another basic value, namely the dignity of a person (in this case - the right to a good name). In one of its judgments, the Supreme Court ruled that "a person whose personal rights have been violated by the publication of a press release is entitled to protection even if the author of the publication has complied with due diligence in the collection and the use of such press material"24 [3]. In this case, personal rights should be understood as referring to the dignity of a person, which has been undermined by the publishing of false information, and not to the right to

${ }^{21}$ Compare with B. Klimkiewicz, Mniejszości narodowe sferze publicznej: reprezentacje, praktyki i regulacje medialne, Kraków 2003.

22 "The current law on radio and television, as L. Szot points out, contains the seeds of 'a quasicensorship' relating to the out-of-court right of the National Broadcasting Council and its President to react in the event of a breach of Christian values and the Polish state interests (Art. 18 of the Act)". L. Szot, Niezależny dziennikarz - rzeczywistość czy fikcja?, in: Media a demokracja..., p. 218

${ }^{23}$ In one of the judgments, the court stated that "it is impossible to accept a situation in which a journalist may make critical assessmentsonly if he can prove their veracity". Quotation from A. Barć - Krupińska, Wolność prasy a dobra osobiste, in: Media a demokracja ..., p. 200.

${ }^{24}$ Quotation from A. Barć - Krupińska, Wolność prasy a dobra osobiste..., p. 196. 
privacy $^{25}$, which, as it seems, can be violated only by the publication of truthful information [31].

When discussing the position of courts in this context, it is worth noting that the relationship of media with the judiciary is not limited only to the possibility of limiting the freedom of the former by the latter. In practice, one can actually face a reverse situation. This is primarily about the publication of lawsuit reports. Such reports do often seem to exert a certain form of influence on the decisions of other courts, and sometimes one can have the impression that media are trying to exert such pressure on the independent judiciary. Any such attempts to consciously exercise influence on the law enforcement agencies and courts should be regarded as morally reprehensible.

The above-mentioned legal restrictions that can be placed on the freedom of media are a cause of much concern that this freedom, and thus the basic foundations of democracy, are threatened. But also the ethics of media itself is sometimes complained about as if it constituted a form of violation of media freedoms. Contrary to appearances, however, this assertion does not seem to be completely unfounded, and taking into account the fact that the goal of any ethical norm is to define the limits of freedom of one entity in order to protect the freedom of another, this 'violation' of freedom should be considered as a primary goal of the media ethics. Certainly, in practice the reason behind these concerns is not the desire for an unfettered and irresponsible freedom, but the fear of furnishing the code of ethical rules with a theory which principles cannot be accepted by all. In Poland, an example to this is the rule to respect Christian values in media, as proscribed in the Act on the National Broadcasting Council.

The view that press committees and ethical codes can become a tool to control media was also expressed by an American author, John C. Merrill. According to this author, there is no fundamental difference between the political and ethical dictate, because both of these means of control do sooner or later lead to the restriction being placed on the freedom and pluralism of media ${ }^{26}[6]$. It should be noted, however, that this view applies to American conditions where there is a habit of signing commitments to be bound by the codes of ethics (generally, however, they are internal to all editorial offices), whereas the position of press committees is far stronger than in Poland.

But in order to provide the answer to questions on the ethical basis for any possible restrictions upon the freedom of media, one must first identify the rationale for

\footnotetext{
${ }^{25}$ In discussions on the meaning of the term "privacy" attention is drawn to its relationship with the concept of dignity, as pointed out by M. Zaremba in Granice prawa obywateli do informacji o życiu prywatnym osób prowadzacych działalność publiczna, „StudiaMedioznawcze” 2005, No. 1 (20), p. 40 et seq.

${ }^{26}$ Compare with E. E. Dennis, J. C. Merill, Basic Issues in Mass Communication. A Debate, New York, London 1984, p. 162 et seq.
} 
the principle of freedom itself. This principle encompasses the right to have opinions as a precondition for other human rights. It is because human rights of individuals exist only when their enforcement is made possible and it is in turn only possible when free access to information is not denied. The right to freedom of expression is not the entitlement of journalists and media, but it belongs to citizens of democratic states, and it is a fundamental right. In addition, this right is not only a moral principle, but it is anchored in international and national legal acts. The first such document, adopted by the UN in 1948, was the Universal Declaration of Human Rights. Its Article 19 states: "Everyone has the right to freedom of opinion and expression; this right includes freedom to hold opinions without interference and to seek, receive and impart information and ideas through any media and regardless of frontiers". The freedom of information and expression are treated herein as being subordinate to the freedom of opinion. In other words, therefore, as one might infer, the right to hold opinions is a fundamental tenet and the right to freely disseminate and access information is a consequence of that primary right.

This distinction seems to be particularly important when we discuss media freedoms as such (and not only in the context of current affairs broadcasts). The question that arises here is therefore to what extent is the interference in the freedom of media justified looking from the point of view of the freedom to hold opinions. There is no doubt that some restrictions, such as the prohibition on pornography or non-broadcast of programmes containing scenes of violence at certain times, are essential. But there are many situations causing controversy, and they are also of ethical character. One example could be restrictions imposed by the authorities of certain countries (for example, France) on importing foreign entertainment programmes in order to protect the native culture. As mentioned before, according to the supporters of this type of solution, an unlimited freedom of media is a threat to democracy.

The vast majority of pundits and media experts believe, however, that the freedom of media is one of the fundamental ethical principles, arising from the right to information that belongs to every individual. From this point of view, to say that the freedom of media is one of the foundations of modern democracy should be considered as too narrow, and with certain interpretations even as downright dangerous. If such freedom really was nothing more than one of the pillars supporting the democratic political system, then it would be enough to secure it only insofar as media come into contact with the political life. However, the majority of contemporary media ${ }^{27}$ deals with neither the politics, nor democracy or civil society (or it does so only marginally), and so it is difficult to talk about their influence on the political system.

\footnotetext{
${ }^{27}$ What I mean here is the majority of press, radio and television titles as well as most of the media content.
} 
It seems that the principle of the freedom of media should be seen as a consequence of the freedom of an individual, according to which no one, especially those holding political powers, has the right to restrict one's freedom of thought and one's right to hold an independent opinion about the world. The freedom to hold opinions should be understood as encompassing the possibility of building one's own viewpoint about the world (and so one's owninterpretationsof the whole of reality), as well as the freedom to hold opinions about certain fragments of that reality. This last caveat is important, because those supporting the placing of restrictions on the freedom of media could protest here, claiming that there are certain areas about which only some people should know, whereas common access to them would bring more harm than good (an example to such restrictions was in the past a prohibition to read the Old Testament by anyone without a pastoral ordination). Therefore, Z. Sareło rightly draws the attention to the fact that it is our moral obligation to ensure the freedom of all media, regardless of their nature, scale and type of impact ${ }^{28}$ [22].

On the other hand, however, in some democratic countries, the principle of the freedom of media seem to become a form of $\operatorname{dog} \mathrm{ma}^{29}$ that no one factually dares to criticise $^{30}[23 ; 5]$. Certainly, this statement does not mean that the freedom of media does not deserve any acceptance as a tenet of modern democracy, yet there is no doubt that to treat freedoms this way does impose a number of risks ${ }^{31}$ [20]. It is worth noting that the existence of these threats was already known to the opponents of the freedom of press in the XVIII and XIX centuries, and so at the time when the press began to clearly articulate its plea for a total freedom. For example, Pope Gregory XVI claimed in the encyclical Mirarivos that to demand the freedom of press equals to a request of the 'freedom of error'. The freedom of press was compared in the encyclical to a

\footnotetext{
${ }^{28}$ "The fundamental right of freedom of communication is indivisible. Therefore, it extends to media supporting the authority and those opposing it; serious and tabloid press". Z. Sareło, Media w stużbieosoby..., p. 75.

${ }^{29}$ The fear of limiting media freedom sometimes takes a bizarre form. As J. Skrzypczak observes, the journalistic environment was until recently rather unfavourable to the idea of creating a professional journalistic self-government, arguing that this endeavour would endanger the freedom of speech.Compare with J. Skrzypczak, $W$ kwestii powołania samorzadu zawodowego dziennikarzy uwag kilka, in: $W$ kręgu mediów i polityki, as edited by D. Pintek, Poznań 2003, p. 132.

${ }_{30}$ According to H. Boventer, this dogma grows out of the prevailing culture model and therefore it is not a universal dogma. Compare with H. Boventer, Pressenfreiheit ist nicht grenzenlos. Einführung in die Medienethik, Bonn 1989, p. 76 et seq.

${ }^{31}$ The conviction that free media is a prerequisite for the existence of democracy is in conflict with the mechanisms by which the very media operate. It is worth adding here that it may be appropriate to distinguish between the freedom to fulfil an information function and the freedom to fulfil a factual function. This function, which consists of establishing and maintaining an emotional contact with the largest possible audience, is distinguished by W. Pisarek. It seems that the freedom of the latter category should also be subject to restrictions.Compare with W. Pisarek, Język $w$ mediach, media $w$ języku, in: Język $w$ mediach masowych, as edited by J. Bralczyka, K. Mosiołek-Kosińskiej, Warszawa 2000, p. 16
} 
poison being sold to the public. But the freedom of press was perceived in a similar way by the governments of various countries, which tried to suppress it by establishing censorship offices ${ }^{32}$ [8].

H. Albrecht points out that currently media, and especially those electronic ones, become a kind of postmodern religion. According to this author, such a comparison is possible because of a number of similarities between media and religion as such, not least with reference to their functions and the ways of communicating with them. Media reproduce certain rituals whose purpose is to develop in the recipients (i. e. the followers) a set of fixed habits of response and perception of the surrounding reality. In contrast to religion, however, media image of the world is not arranged in a coherent whole, but it consists of many chaotic fragments that appear in a random order. This also applies to values and ethical standards, which do not form a compact structure, but are presented by media as a form of 'buffet' from which everyone can choose what suits them best ${ }^{33}$ [1].

In this case, although the recipient is indeed left alone to make a fully autonomous choice, he is not really equipped with any key that would allow him to choose those values serving his good and the good of the society. The fragmentary and chaotic picture of the world as presented in media creates the impression that such a single criterion (or criteria) does not in fact exist, and the true freedom comes down to a sense of confusion and disorientation. This is how media contribute to the strengthening of social attitudes of nihilism and certain convictions relating to the meaninglessness of living, not to mention about the treatment of consumption as the only way of gaining satisfaction from life. Through the selection of content and form of communication, media in fact discourage from the use of freedom, and so de facto they take this freedom away.

Some ethical doubts do also arise when it comes to the attempts by media to 'commercialise' some commonly accepted values of the society. Such a value is family, for example. According to an English author of guidebooks for housewives and a specialist in the field of history of societies, Christina Hardyment, the invention of television is one of the three factors (in addition to contraception and the invention of washing machines), which have had the greatest influence on the position of women in the family, and thus on the functioning of the whole family ${ }^{34}$ [10]. Although the author draws the attention to the mere existence of television as a factor responsible for changes in the functioning of families, yet currently media are trying to influence families in a manner that is fully conscious. This impact can occur, for example, by broadcasting 'family' programmes, which are addressed to whole families and which

\footnotetext{
${ }^{32}$ Compare with S. Gęsiarz, A. Kudłaszyk, Cenzura w Królestwie Polskim - Rzeczpospolitej szlacheckiej, in: Mass media w systemie komunikacji społecznej w Polsce, Wrocław 1995, p. 5 et seq.

${ }^{33}$ Compare with H. Albrecht, Die Religion der Massenmedien..., p. 107 et seq.

${ }^{34}$ Compare with Ch. Hardyment, Rodzina, Warszawa 1999, p. 18.
} 
contain a model of an ideal household and its relations with its social environment, which some customers may see as a role model to follow. Another example of such an interference are magazines for women, which contain various forms of advice on wifehusband relationships as well as on raising the children or leisure activities. Finally, media affect families by their very presence in the households, where a TV set is typically centrally located, becoming the most important 'household member'.

It is part of a wider phenomenon, involving the replacement of the real world with media reality. The recipient treats various television characters as heroes, imitating their manners, speaking, thinking and finally their evaluation of the reality ${ }^{35}$ [30]. Although it is difficult to talk about a deliberate reduction in the degree of the freedom of choice here, certainly, the recipient's scope of autonomy is considerably narrowed. The recipient is not so much deprived of his liberty as he deprives himself of it on his own, allowing for the media to take control of his mind. Any such resignation from personal freedoms can cause an unmitigated dependence on media, leading to profound and negative changes occurring on the personality and behavioural level of the recipient (neglecting work, family breakdowns, loss of friends, etc.) ${ }^{36}[8]$. Whereas an aware enslavement occurs when media try to influence their recipients as consumers, for example by artificially arousing their needs and then inciting them to satisfy these by buying specific products ${ }^{37}[14]$.

The interference with the freedom of an individual may also take place by challenging certain values. This sort of dealings by media can be often found in the sphere of customs. And it is not only about challenging one custom or another, but rather about rejecting certain values altogether that give foundations to customs or traditions. This situation can be compared to the questioning of private property, because every person has the right to have one's own values, beliefs and convictions which cannot be subjected to ridicule or any other form of ostracism. To present certain behaviours and opinions in media as anachronistic, backward and outmoded should be regarded as contrary to the right of every man to hold opinions. The freedom of media, which is the realisation of this very right to hold opinions, turns itself in this way against its own foundations, and so therefore it questions itself.

The trend why certain values are 'commercialised' while others are questioned stems from a form of 'dualism' of media messages in a sense that such coverage does not only serve to inform and entertain (or both simultaneously), but also to urge its recipients for an increased media reception. In other words, media do not only inform or entertain, but they also say 'watch me'. This persuasive dimension of communication does not have to be expressed directly and sometimes it is imputed into

\footnotetext{
${ }^{35} \mathrm{~L} . \mathrm{W}$. Zacher, Telewizja jako spolecznie ryzykowne medium $i$ forma przekazu informacji $i$ wartości, in: Rewolucja informacyjna i społeczeństwo, Warszawa 1997, p. 129.

${ }^{36} \mathrm{Op}$ cit. at note 35 p. 134.

${ }^{37}$ Compare with T, Kowalski, Media i pieniądze. Ekonomiczne aspekty działalności środków komunikowania masowego, Warszawa 1998, p. 37.
} 
the very content of the message itself. Its main goal is then to entice the recipient into staying at the receiver or buying the next issue of a magazine. From the point of view of an impact on the recipient, the form of communication seems to be more important than its content. "How we speak, according to J. Tischner, creates a bond between the speaker and the listener. (...) This 'how' decides whether I am talking 'to', 'against' or 'with' someone. And this is how we happen to touch upon the place from which the power of words grows" ${ }^{38}$ [28]. As noted by W. Dreier, this urging does always contain a certain element of enslavement, which is all the more bigger depending on how camouflaged the persuasive message is and how much aware of it the sole recipient becomes $^{39}$ [7]. This does not mean, though, that one should prohibit media from transferring their content in a form that will serve as an advertising impelling to 'buy' their products. Yet, it is worth insisting that this persuasive layer should be made readable and understandable for the recipient. Only when fully aware of the real objectives of individual media messages can the recipient be in a position to take a stance in a fully autonomous manner, and this is also when it comes to his views on the media themselves.

A separate issue relating to the freedom of media concerns the ethical assessment of the ways to counter any restrictions placed upon this freedom. One should pay attention here to the relationship of media employees with their employing institutions. As I have mentioned, any relationship with one's employer is always associated with the risk of limiting the employee's personal freedoms, the scope of which is generally dependent on the good will of the superiors. On the other hand, however, even if renouncing some part of their independence, journalists do not bear full responsibility for the consequences of their work. As noted by S. Mocek, "a journalist, while identifying himself with the medium which he represents, perceives it by definition as a guarantor of his independence" ${ }^{\text {"40 }}$ [16]. This means that the journalist does cede some part of his personal freedoms onto his employer, receiving in return the protection of this part of the freedom which he has not ceded.

The release from some part of personal responsibility, sometimes also from direct pressures, does indeed guarantee individual freedoms of journalists. This fact is particularly important for journalists providing information to news agencies, because they do not have to worry about unpleasant consequences if the information so provided turned out to be false. Such a guaranteed safety has also a positive effect on the freedom of expression of opinions, which seems to be at a higher risk because of a legal requirement to comply with the 'programme line' of the medium in question. And so alongside obvious abuses arising from the employment relationship, one can also indicate certain forms of mutual dependence. This in the world of media pluralism

\footnotetext{
${ }^{38}$ J. Tischner, Siła stowa: Radio. Szanse $i$ wyzwania. Materiaty z konferencji 'Kulturotwórcza sita radia', Kraków 1997, p. 103.

${ }^{39}$ W. Dreier, Funktion und Ethos der Konsumwerbung, Münster 1965, p. 270.

${ }^{40} \mathrm{~S}$. Mocek, Dziennikarze po komunizmie..., p. 168.
} 
contributes to the growth of the general quality level of media and their reliability, even despite apparent contradictions with the principle of media independence.

These dependencies concerning individual journalists and their media employers should be distinguished from the relationship between an editorial office and the media owner. This dependence, particularly when turning into a source of restrictions on the freedom of media, is difficult to be justified in any way. The only limitation that cannot be assessed in an unambiguously negative way is a ban on publishing by media belonging to a specific owner certain material which would put that owner in an undesirable light or harm his interests. To demand that in such a situation the freedom of media should allow for the publishing of a harmful content is tantamount to allowing the owner to act to his own detriment.

It is worth noting that an analogous situation exists in the criminal judicial process, where neither the accused nor the witnesses must be compelled to testify if doing so would expose them to criminal liability. This prohibition, however, does not cover different types of damage, including financial, but it is an example to the rule allowing for the withdrawal of certain information due to one's own specific interests. This does not mean that media owners should be allowed to suppress any information and opinions, which if published would have an adverse effect on their social standing. It only means that under some reasonable limits one can accept the moral right of a media owner to influence their own media company in order to protect their evident interests. An example to this might be the intention to disclose certain data that could be used by one's business competitors.

What is not acceptable, however, is to treat one's media only as a form of profitable enterprise. Otherwise, we would have to agree that the owner has the right to defend not only his immediate interests but also those of his advertisers, upon whose profits he in fact depends. The tools used by media owners to restrict the freedom of media include, among others, the issuing of prohibitions on the publication of 'an inconvenient content' (with few exceptions), the reduction of funds for a given purpose, the hiring of editors (directors) professing certain beliefs while making redundant others or taking away bonuses and prizes.

The excessive amount of such prohibitions and restrictions leads to the appearance of various mechanisms of self-censorship in media, blocking the publication of certain content much more effectively than it could be done otherwise by formal censorship ${ }^{41}[16]$. This is a fact well-known for various organised groups (which are not only political, but also cultural, religious, etc.), which try to pressurise media in order to subject specific content to further self-censorship. Letters to the editor, phone calls, fax messages and organised pickets to defend some values are all

41 Also during the period of the Polish People's Republic media content was subject to censorship. "The journalists knew, as S. Mocek writes, what can and should not be written, what to put and what to avoid in television scripts of news programmes so as not to be exposed to the hardship and harassment of the power". S. Mocek, Dziennikarze po komunizmie..., p. 72. 
forms of this pressure. As noted by T. Goban-Klas, "even though most apparently it looks like a spontaneous outcry of the public opinion, in fact, however, it is an extremely well-organised campaign of pressure"42 [9]. Such a situation is contrary to both the principle of the freedom of media as well as the principle of openness and truthfulness, because its point is to lead media employees into error as to the real intentions of protesters. One should also mention about the activities of public relations specialists, who according to some sources produce the majority of information on the operation of various organisations, institutions and companies that are published in media. According to T. Goban-Klas, "the PR is like a theatre director - it does not show up on the scene and it remains in the shadows so that not to outshine the actors who, after all, play according to his concept". The ethics of public relations (just like the ethics of advertising) is not directly covered by the ethics of media, but it is worth noting that it does not allow to mislead anyone, especially the media. Yet another form of pressure is to publish a large amount of expensive advertisementsin media and then to threaten their withdraw in the event of publication of certain content (for example ecological) ${ }^{43}$ [9]. In this case, however, it is no longer about the self-censorship but about a sheer blackmail, which is always a morally reprehensible deed.

A serious limitation to the freedom of media can finally be posed by a variety of 'technical' problems on the side of the recipient and the sender. In the first case the issue concerns situations where the reception of media coverage is restricted on account of the lack of physical access to media (especially modern media, such as the Internet - a problem that currently affects most of the world's population) or inadequate intellectual preparation. In this context, J. Volek argues about the primary and secondary 'information illiteracy'. According to this author, the first category of 'information illiteracy' occurs when citizens have a limited access to information on account of their education, wealth or class affiliation. Such people cannot access information that would otherwise allow them to solve their problems, while at the same time not being able to realise that these problems can be solved through access to information. In turn, secondary 'information illiteracy' arises when individuals who have sufficient education and economic means tend to ignore all information that is not related to their specialisation. This makes them lack any knowledge that is beyond their field, and so they are on an equal footing with those who are affected by the primary 'information illiteracy' ${ }^{44}$ [29]. In an individual dimension these are not significant limitations, because both primary and secondary 'information illiteracy' can be relatively easily overcome by self-development. The problem becomes more serious in the social dimension and so it imposes on media an obligation to develop ways of

\footnotetext{
${ }^{42}$ T. Goban-Klas, Granice wolności mediów, in: Dziennikarstwo i świat mediów..., p. 419.

${ }^{43}$ Ibid.

${ }^{44}$ J. Volek, Niezamierzone skutki , komunikacyjnej ideologii”..., p. 53
} 
overcoming this sort of illiteracy, for example, by broadcasting educational programmes for adults.

Analogous difficulties arise also on the side of media. The phenomenon of 'information illiteracy' here takes the form of a simple lack of professionalism ${ }^{45}$. This problem was particularly acute during the first years of political transition in Poland, when media people were recruited literally 'from the street'. Some of them have worked in media ever since, and some have become media celebrities. The incompetence of the Polish media employees is no longer an issue today, but it is difficult not to get the impression that its place was taken by a total lack of selfcriticism. This attitude is summarised by C. J. Bertrand as follows: "a number of media people, who have after all decided for life in the spotlight, tend to continuously besmirch various important personalities while in fact showing no ability to accept their own criticism. Perhaps some people suffer from an oversensitive ego inflated as a result of being in the company of outstanding individuals. Considering that a form of mutual backbiting and slandering one's own profession is in the private lives of journalists a common phenomenon, one may ask if a prevailing inferiority complex is not hidden under this fear-induced journalistic arrogance" ${ }^{46}$ [4]. This attitude does obviously affect the content of media messages. The obligation of continuing education and improving one's quality of work is therefore in this context the result of a recipient's right to information.

The duty of media should also be to oppose any popular beliefs and stereotypes. The fulfilment of this obligation is certainly not easy, because a significant portion of these popular opinions and stereotypes has been created through media and continues to be maintained by them. Yet, what can be observed in media is a form of reluctance to present any opinions which might be contrary to the views presented by the majority. Media tend to deal with the same themes (often simultaneously), presenting uniform and simplified assessments. This undermines the principle of media pluralism, which is in fact a different formulation of the principle of pluralism of views and assessments, which then is clearly contrary to one's right to hold free opinions. Paradoxically, this reluctance to present independent opinions may result from some sort of fear that these opinions will be treated as a critique of media freedoms, and thus as a breach of the principle of solidarity. And because the principle of solidarity serves the superior principle of freedom to express one's opinions, therefore in a situation of conflict with this latter overarching principle, the former ceases to apply.

Conclusions. Two important conclusions can be drawn from the foregoing analysis. Firstly, the classification of various threats to media freedoms seems particularly important in any ethical consideration. It is because it allows to formulate

\footnotetext{
${ }^{45}$ The informational poverty on the part of the recipient can be defined, by analogy, as a lack of "receiving competence" or "media ignorance".

${ }^{46}$ C. J. Bertrand, Deontologia mediów..., p. 238.
} 
specific standards, the realisation of which can be demanded by the recipients. Secondly, media freedoms understood as the opportunity to pursue one's own goals (interests) does often come into conflict with the freedom of the recipient (the individual and the society) to obtain adequate information enabling to make the right decisions (for example to vote in elections). This conflict is not always resolved in favour of the public, although some authors are of the opinion that the interests of the society or the individual should take precedence over the principle of freedom of media $^{47}$ [25]. Some restrictions on such freedoms, as imposed by different codes of ethics or by the law, may be in the long term fairly beneficial because they may force media to improve the quality of communication. Such function is fulfilled by a prohibition on the use of profanity in the entertainment programmes or the legal protection of privacy, etc.

There are also situations where on account of a prevailing set of views in a given society the suppression of the freedom of media is sanctioned. And the reverse is true - sometimes media might restrict the freedom of having opinions by those who do not share any such commonly accepted views. Any immoderate use of media might also sometimes become the cause of resignation from internal autonomy and a consequent voluntary submission to the external, chaotic stimuli, which can only entail negative consequences for all dimensions of human life. In such cases, the principle of the freedom of media turns against the philosophical basis from which it arises, namely - the right of every individual to freedom. On account of an intense process of changes taking place in the society and media themselves, one can formulate a rule requiring a continuous analysis of these changes in terms of any possible threats to both the freedom of media and the freedom of an individual.

\section{Bibliography:}

1. Albrecht, H. Die Religion der Massenmedien. Stuttgart; Berlin; Köln : Kohlhammer, 1993, p. 107 et seq.

2. Balsey, A., Chadwick, R. Ethics as a Vehicle for Media Quality, in: The Media and Morality, as edited by R. M. Baird, W. E. Loges, New York, 2002, p. 56

3. Barć-Krupińska, A. Wolność prasy a dobra osobiste [w:] Media a demokracja podred. L. Pokrzyckiej i W. Micha, Wydawnictwo UMCS, Lublin 2007.

4. Bertrand, C.J. Deontologia mediów, Warszawa, 2007, p. 96, p. 238

5. Boventer, H. Pressenfreiheit ist nicht grenzenlos. Einführung in die Medienethik, Bonn 1989, p. 76 et seq.

\footnotetext{
${ }^{47}$ It should be emphasised, however, that social interest is not the same as the interest of the institutions representing the society. It would certainly be in the interests of justice to abolish the journalistic secrecy but not in the interest of the public. Such a position is prevailing in the current Polish law. Compare with J. Sobczak, Tajemnica dziennikarska ..., p. 20. 
6. Dennis, E.E., Merill, J.C. Basic Issues in Mass Communication. A Debate, New York, London 1984, p. 162.

7. Dreier, W. Funktion und Ethos der Konsumwerbung, Münster 1965, p. 270.

8. Gęsiarz, S., Kudłaszyk, A. Cenzura w Królestwie Polskim - Rzeczpospolitej szlacheckiej, [w:] Mass media w systemie komunikacji społecznej w Polsce, Wrocław 1995 , p. 5 et seq.

9. Goban-Klas, T. Granice wolności mediów. Wolność mediów - od kogo i od czego? [w:] Dziennikarstwo i świat mediów, pod redakcją Z.Bauera i E.Chudzińskiego, Krakow, Universitas, 2008, ss. 543-556

10. Hardyment, Ch. Rodzina, Warszawa: Prószyński i Ska 1999, s. 13-28.

11. Kamińska, K. Obiektywizm i samokontrola $w$ wypowiedziach estońskiej prasy codziennej na początku XXI wieku, [w:] Media a demokracja..., p. 289.

12. Klimkiewicz, B. Mniejszości narodowe sferze publicznej: reprezentacje, praktyki i regulacje medialne, Kraków 2003.

13. Kononiuk, T. Prywatność w mediach, [w:] Studia Medioznawcze, 2005, No. 1 (20), p. 30.

14. Kowalski, T. Media i pieniadze. Ekonomiczne aspekty dziatalności środków komunikowania masowego, Warszawa 1998, p. 37.

15. Matejko, A., Postawy zawodowe dziennikarzy na tle systemu społecznego redakcji, Warszawa, 1962, 1963.

16. Mocek, S. Dziennikarze po komunizmie, Wydawnictwo Naukowe Scholar, Warszawa 2006, s. 258.

17. Nałęcz, D. Zawód dziennikarza w Polsce 1918 - 1939, Łódź 1982, p. 49 et seq.

18. Olędzki, J. (red.), Media, reklama i public relations w Polsce, Warszawa 2005, s. 268.

19. Pietrzykowski, K. Tzw. ,interpretacyjne wyroki Trybunału Konstytucyjnego, „Przegląd Sądowy” 2004, No. 3, p. 16

20. Pisarek, W. Język $w$ mediach, media $w$ języku, [w:] Język $w$ mediach masowych, as edited by J. Bralczyka, K. Mosiołek-Kosińskiej, Warszawa 2000, p. 16

21. Pokrzycka, L. Kapitat zagraniczny $w$ regionalnej prasie - szanse $i$ zagrożenia dla dziennikarzy (analiza na przykładzie Lubelszczyzny), [w:] Media a demokracja, pod red. L. Pokrzyckiej i W. Micha, Lublin, 2007, s. 245-252.

22. Sareło, Z. Media w stużbie osoby. Etyka społecznego komunikowania. Torun : Adam Marszałek, 2002, 194 s.

23. Skrzypczak, J. $W$ kwestii powotania samorzadu zawodowego dziennikarzy uwag kilka, in: W kręgu mediów i polityki, as edited by D. Pintek, Poznań 2003, p. 132.

24. Ślipko, T. Zarys etyki szczególowej, Kraków 1982, V. I, p. 360 et seq.

25. Sobczak, J. Tajemnica dziennikarska, Studia Medioznawcze, 2005, nr 1, s. $20-25$. 
26. Szot, L. Niezależny dziennikarz. Rzeczywistość czy fikcja?, w: Media a demokracja, pod red. L. Pokrzyckiej, W. Micha, Lublin, 2007., p. 218

27. Thompson, J. B. Media i nowoczesność. Spoleczne teorie mediów, Wrocław 1996, p. 135.

28. Tischner, J. Siła stowa: Radio. Szanse i wyzwania. Materialy z konferencji 'Kulturotwórcza siła radia', Kraków 1997, p. 103.

29. Volek, J. Niezamierzone skutki „komunikacyjnej ideologii”, [w:] Media masowe w demokratyzującycg się systemach politycznych. W dradze do wolności słowa i mediów, red. B.Dobek-Ostrowska, Wroclaw, 2006, p. 53

30. Zacher, L. W. Telewizja jako społecznie ryzykowne medium i forma przekazu informacji $i$ wartości, [w:] Rewolucja informacyjna $i$ społeczeństwo, Warszawa 1997, s. 128.

31. Zaremba, M. Granice prawa obywateli do informacji o życiu prywatnym osób prowadzących działalność publiczna, 2005, No. 1 (20), p. 40 et seq.

(c) Czarnecki P., 2018 